УДК 330.43:314.74

DOI: https://doi.org/10.37320/2415-3583/9.30

Негрей М.В.

кандидат економічних наук, доцент, Національний університет біоресурсів і природокористування Украӥни ORCID: https://orcid.org/0000-0001-9243-1534

Комар M.I.

кандидат економічних наук, доцент, Львівський національний університет імені Івана Франка

\title{
МОДЕЛЮВАННЯ МІГРАЦИЙНИХ ПРОЦЕСІВ В УМОВАХ НЕВИЗНАЧЕНОСТІ ЕКОНОМІЧНОЇ ПОЛІТИКИ
}

Статтю присвячено дослідженню проблеми сучасних міграційних процеесів та оцінці впливу невизначеності економічної політики на міграцію у краӥнах СС. Проведено очінку структури міграції та визначено основні тендениї міграчійних прочесів. Визначено вплив мігращї на суспільні процеси. Встановлено поглиблення існуючих міграційних моделей, оскільки можливості були реалізовані через економічне зростання та реформи, лібералізацію торгівлі та довгострокову стабільність. Проілюстровано зв'язок між економічними, політичними та соціальними питаннями, з одного боку, та міграчією - з іншого. Показано важливість цифрровізації у міграційних проиесах. Досліджено вплив невизначеності економічної політики на міграційні процеси. Побудовано регресійні моделі, які дають змогу зробити висновок щодо відсутності прямого взаємозв 'язку між невизначеністю економічної політики та міграцією у відповідний період часу.

Ключові слова: міграція, міграційний процес, невизначеність, індекс невизначеності економічної політики, регресійна модель.

Постановка проблеми. Однією 3 найбільших проблем XXI ст. стали міграційні процеси. Хоча добровільна та вимушена міграція відбувалася впродовж усього періоду існування людства, проте сьогодні обсяг міграції досяг максимального масштабу. Зрозуміло, що міграційні процеси будуть відбуватися й надалі, до того ж інтенсивність їх зростатиме. Тому необхідним є дослідження сучасного стану міграційних процесів та пошуку нових шляхів провадження міграційної політики.

Аналіз останніх досліджень і публікацій. Вивчення міграції проводиться цілою низкою дослідників, зокрема науковцями, урядами, міжурядовими організаціями та аналітичними центрами. Аналізу та моделюванню міграційних процесів присвячено праці таких вітчизняних учених, як Г. Берегова, В. Козицький [1], Р. Войтович [2], Б. Дмитрук та Н. Свєтлова [3], I. Лук'яненко [6], М. Оліскевич [8; 9] та ін. Перелік науковців можна продовжити, оскільки дана проблематика тісно пов'язана з багатьма іншими соціально-економічними, політичними, демографічними, психологічними та іншими проблемами.

Мета статті полягає у дослідженні проблеми сучасних міграційних процесів та оцінці впливу невизначеності економічної політики на міграцію у країнах ЄC.

Виклад основного матеріалу. Багаторічні зростаючі дані про міграційні процеси свідчать про те, що міграція значною мірою пов'язана 3 глобальними економічними, соціальними, політичними та технологічними чинниками.
Цифровізація сучасного суспільства спрощує доступ людей до інформації, товарів та послуг 3 усього світу. Проте глобалізація супроводжується значною невизначеністю. Також зростає вплив екологічних та кліматичних змін на міграційні процеси.

Рекомендації Організації Об'єднаних Націй щодо статистики міжнародної міграції визначають «міжнародного мігранта» як будь-яку особу, яка змінила країну свого звичайного проживання, розрізняючи «короткочасних мігрантів» (тих, хто змінив країну свого звичайного проживання принаймні на три місяці, але менше одного року) та «довгострокових мігрантів» (тих, хто зробив це щонайменше на один рік). Однак не всі країни застосовують це визначення на практиці. Деякі країни використовують різні критерії для ідентифікації міжнародних мігрантів, наприклад застосовуючи різні мінімальні тривалості проживання. Відмінності понять та визначень, а також методологій збору даних між країнами перешкоджають повній порівняності національної статистики щодо міжнародних мігрантів.

Кількість міжнародних мігрантів оцінюється майже у 272 млн у всьому світі, причому майже дві третини - трудові мігранти [7]. Цей показник залишається дуже малим відсотком світового населення $(3,5 \%)$, це означає, що переважна більшість людей у всьому світі (за оцінками, 96,5\%) проживають у країні, в якій вони народилися. 74\% усіх міжнародних мігрантів були працездатними (20-64 роки). Найбільша кількість мігрантів, які проживають за кордоном, 3 
Індії (17,5 млн), Мексики та Китаю (11,8 млн та 10,7 млн відповідно). Найбільшою країною призначення є США (50,7 млн міжнародних мігрантів). Міжнародні грошові перекази становили 689 млрд дол. у 2018 р. Найбільші одержувачі грошових переказів - Індія (78,6 млрд дол. США), Китай (67,4 млрд дол. США) та Мексика (35,7 млрд дол. США). Сполучені Штати залишаються головною країною, що надсилає грошові перекази (68,0 млрд дол. США), далі - Об'єднані Арабські Емірати (44,4 млрд дол. США) та Саудівська Аравія (36,1 млрд дол. США). Глобальне населення біженців у 2018 р. становило 25,9 млн. Кількість внутрішньо переміщених осіб через насильство та конфлікти досягла 41,3 млн.

Прогнозна кількість та частка міжнародних мігрантів уже перевершує деякі прогнози, зроблені на 2050 р., які становили близько 2,6\%, або 230 млн. Загальновизнано, що масштаби та темпи міжнародної міграції важко точно передбачити, оскільки вона тісно пов'язана 3 непередбачуваними подіями (такими як економічна криза чи військовий конфлікт), а також довготривалими тенденціями (такими як демографічні зміни, економічний розвиток, розвиток комунікаційних технологій та доступ до транспорту). Дослідження довготермінових даних показують, що міжнародна міграція нерівномірна в усьому світі, але формується економічними, географічними, демографічними та іншими чинниками, що призводить до різних міграційних моделей, таких як «коридори» міграції, що формувалися впродовж багатьох років. Найбільші коридори, як правило, йдуть від країн, що розвиваються, до великих економік, таких як США, Франція, Російська Федерація, Об'єднані Арабські Емірати та Саудівська Аравія.

Останніми роками відбулося поглиблення існуючих моделей міграції, оскільки були реалізовані можливості, спричинені економічним зростанням та реформами, лібералізацією торгівлі та довгостроковою стабільністю.

Мобільність $є$ властивою для всіх груп населення, якщо не встановлено конкретних політик чи інших чинників, які обмежують та контролюють цю мобільність. Тим не менше деякі народи, здається, рухаються більше, ніж інші, і відрізняються від інших, що тісно пов'язано з рівнем розвитку в кожній країні, що, своєю чергою, пов'язано з розподілом населення в кожній країні. Незважаючи на всі труднощі $з$ вимірюванням процесів міграції, науковцями досягнуто значного прогресу в напрямі побудови аналітичних моделей, що дають змогу порівнювати структури в просторі. Зростаюча складність досліджень міграції частково пояснюється також тим, що стає доступно більше інформації про міграцію та мігрантів, аніж будьколи раніше. Відомо більше про те, хто мігрує, чому люди мігрують, куди й як вони мігрують, хоча, можливо, цього недостатньо.

Вплив міграції на суспільні процеси полягає у такому:

- Мігранти здійснюють вагомий соціокультурний, громадсько-політичний та економічний внесок у країни та громади, зокрема вони є важливими агентами змін у низці секторів.

- Іммігранти, як правило, мають більш високу підприємницьку активність порівняно 3 корінними жителями. Наприклад, у США мігранти непропорційно сприяли інноваціям.

- Включення мігрантів до приймаючого суспільства стосується різноманітних суспільнополітичних сфер, які тісно взаємопов'язані. Результати включення в одну галузь, такі як мова, освіта, включення до ринку праці, возз'єднання сімей, політична участь та натуралізація, ймовірно, впливатимуть на інші.

- Існує динамічний і складний взаємозв'язок між міграцією та здоров'ям. Міграція може призвести до більшої небезпеки для здоров'я, але вона також може бути пов'язана 3 поліпшенням здоров'я, особливо для тих, хто шукає безпеки.

- Найновіша глобальна оцінка загальної кількості дітей-мігрантів становить приблизно 31 млн. Приблизно 13 млн дітей-біженців, 936 тис дітей, які шукають притулку, та 17 млн дітей, які були насильно переселені у свої власні країни.

- Все більше свідчень про те, що масштаби та частота надзвичайних погодних явищ зростають, й очікується, що це все більше впливатиме на міграцію.

- Останні два роки відбулися суттєві зміни у глобальному управлінні міграцією, головним чином, у формуванні Мережі ООН з міграції та двох глобальних договорах щодо біженців та міграції. Хоча вони не $є$ юридично обов'язковими, дві глобальні домовленості є майже універсальним консенсусом щодо питань, що потребують стійкого міжнародного співробітництва та зобов'язань.

Міграція - важлива політична тема. Протягом останнього десятиліття про політизацію міграції свідчить низка подій: страх у західних країнах припливу маси мігрантів із країн колишнього Радянського Союзу; сумніви щодо ролі мігрантів в економічних та соціальних потрясіннях, спричинених фінансовою кризою в Південно-Східній Азіі; обмежувальна політика та протиміграційна реакція після терактів 11 вересня 2001 р.; поновлені спалахи ксенофобії у кількох африканських країнах, які звинувачують мігрантів у внутрішніх кризах; експлуатація міграційних питань деякими політиками для досягнення виборчої перемоги. Усі ці приклади ілюструють тісний зв'язок між економічними, політичними та соціальними питаннями, з одного боку, та міграцією - з іншого. 
Міграція переплітається 3 технологіями та інноваціями, й існує значна кількість досліджень впливу міжнародної міграції на підтримку (а іноді й обмеження) передачі технологій та знань, часто працюючи в тандемі з інвестиційними та торговельними потоками щодо історичних, географічних та геополітичних зв'язків між країнами та громадами. Цифровізація стає все більш важливою протягом усього міграційного процесу. Наприклад, в останні роки спостерігається використання IКТ мігрантами для збору інформації та консультацій у реальному часі під час міграційних подорожей; питання, яке викликає інтерес і часом хвилює. Використання IКТ, таких як додатки для обміну найновішою інформацією, у тому числі для підтримки підпільних перетинів кордону, разом із консолідацією платформ соціальних медіа для з'єднання географічно розсіяних груп зі спільними інтересами викликало вагомі питання щодо того, наскільки технології використовуються для підтримки нерегулярної міграції, а також для того, щоб мігранти могли уникати зловживань та експлуатації контрабандистів мігрантів та торговців людьми. Через постійно зростаючий доступ до нових технологій за низькою ціною мігранти також розробили програми для підтримки кращої інтеграції у приймаючих країнах, зберігаючи соціальні зв'язки та фінансову підтримку своїх сімей та товариств, у тому числі через збільшення кількості програм «мобільних грошей».

Інші зв'язки між міграцією та технологією також з'являються в дебатах про міграцію. Оскільки штучний інтелект прогресивно застосовується у ключових секторах, його наслідки для потоків робітничих мігрантів та внутрішніх ринків праці є сферами, що сильно фокусуються для розробників політики та бізнесу в країнах походження та прийому.

Нещодавні дискусії також стосуються технологіï blockchain та iii наслідків для міграції, особливо для грошових переказів, а також для цифрової ідентичності та глобальної мобільності. Технології соціальних медіа також усе більше впливають на міграційну політику, залучаючи крайньо правий активізм на платформи соціальних медіа, які прагнуть впливати на політичні дебати та в кінцевому підсумку на політичні рішення.

Безпрецедентний темп змін у геополітичній, соціальній, екологічній та технологічній сферах призвів до того, що темпи змін перевершують усі очікування та прогнози. Такі зміни часто призводять до несподіваних і небажаних наслідків. У рамках цих зрушень міжнародна міграція все більше використовується як політичний інструмент, підриваючи демократію та спричиняючи зрозумілий страх у громадськості, що випливає 3 прискорених темпів змін та зростаючої невизначеності нашого часу.
3 огляду на вищесказане, вважаємо доцільним оцінити вплив невизначеності економічної політики на міграційні процеси.

Для дослідження впливу невизначеності політики на сукупні інвестиції, виробництво та зайнятість використовують новий підхід - індекс EPU (Economic Policy Uncertainty). У результаті дослідження невизначеності економічної політики дійшли висновків, які у цілому узгоджуються 3 теоріями, що підкреслюють негативні економічні наслідки шоків невизначеності. Масштаби оціночних ефектів говорять про те, що підвищена невизначеність політики у США та Європі в останні роки мала істотний шкідливий вплив на макроекономічні показники. На нашу думку, застосування даного показника для оцінки впливу невизначеності економічної політики на міграційні процеси може дати цікаві результати.

Індекс EPU (Economic Policy Uncertainty) розраховують на основі частоти публікації газет, оцінюється невизначеність економічної політики, які економічні заходи впроваджуватимуться та економічні наслідки політичних дій (або бездіяльності), включаючи невизначеність, пов'язану з економічними наслідками «неекономічних» питань політики, наприклад військових дій. Оцінка невизначеності економічної політики охоплює як короткострокові проблеми, так і довгострокові проблеми.

Розрахунок EPU був побудований у першу чергу для США з 1985 р. Сучасний щомісячний індекс EPU для США грунтується на публікаціях 10 провідних газет: USA Today, Miami Herald, Chicago Tribune, Washington Post, Los Angeles Times, Boston Globe, San Francisco Chronicle, Dallas Morning News, New York Times ta Wall Street Journal.

На додаток до щомісячного індексу також розраховується щоденний індекс EPU, використовуючи агрегатор новин Newsbank, який охоплює близько 1500 газет у США. Широке висвітлення Newsbank дає достатньо статей для створення значущого щоденного розрахунку. Порівняння середніх місячних та середніх щоденних індексів показало, що кореляція між ними становить 0,85 .

Індекси EPU також розраховуються для одинадцяти інших великих економік. Як і в американському індексі, щомісяця оцінюють кількість статей, що містять потрійну фразу про економіку (Е), політику (Р) та невизначеність (U). Потім масштабують розрахунки, стандартизують варіації кожної газети, середнє значення серед газет у країні за місяцями та проводять нормалізацію. Усі пошуки проводять рідною мовою газети, спираючись на архіви семи газет в Індії, по шість у Канаді та Південній Кореї, по дві - у Франції, Німеччині, Італії, Японії, Іспанії та Великобританії та по одній - у Китаї та Росії. 
Таблиця 1 - Дослідження впливу невизначеності економічної політики на міграційні процеси

\begin{tabular}{|l|c|c|c|c|c|}
\hline \multirow{2}{*}{ Germany } & & $\boldsymbol{b}_{\boldsymbol{0}}$ & $\boldsymbol{b}_{\boldsymbol{1}}$ & $\boldsymbol{R}^{\mathbf{2}}$ & $\boldsymbol{p}$-value \\
& Immigration & 52584.06 & 66.46 & 0.015 & 0.094 \\
\cline { 2 - 6 } & Emmigration & 28755.81 & 17.78 & 0.001 & 0.355 \\
\hline \multirow{2}{*}{ Italy } & Immigration & 35810.73 & -43.19 & 0.049 & 0.009 \\
\cline { 2 - 6 } & Emmigration & 9994.29 & -3.45 & 0.006 & 0.589 \\
\hline \multirow{2}{*}{ Knited } & Immigration & 47898.46 & 2.69 & 0.005 & 0.208 \\
\hline \multirow{2}{*}{ France } & Emmigration & 29121.26 & -1.63 & 0.0001 & 0.322 \\
\hline \multirow{2}{*}{ Spain } & Immigration & 24891.94 & 12.62 & 0.228 & $2.151 \mathrm{e}-08$ \\
\cline { 2 - 6 } & Emmigration & 21775.29 & 7.65 & 0.063 & 0.003 \\
\cline { 2 - 6 } & Immigration & 33511.20 & -8.18 & 0.006 & 0.613 \\
\hline
\end{tabular}

Для визначення впливу невизначеності економічної політики вибрано європейські країни, для яких оцінено індекс EPU: Німеччина, Італія, Великобританія, Франція та Іспанія. Діапазон моделювання - 2007-2018 рр. Побудовано регресійні моделі залежності кількості емігрантів та іммігрантів (для кожної країни дві окремі моделі). Отримані результати представлено в табл. 1.

За результатами моделювання дійшли висновку, що невизначеність економічної політики не справляє значного впливу на міграційні процеси.
Висновки. Результати дослідження впливу невизначеності економічної політики на міграційні процеси показали відсутність взаємозв'язку між ними. Проте, на нашу думку, дане дослідження доцільно продовжити. Перспективними дослідженнями $є$ встановлення впливу невизначеності економічної політики на міграційні процеси з лагом, оскільки рішення про міграцію приймаються зазвичай не швидко і процес міграції потребує часу. Також доцільно розширити часовий діапазон та дослідити країни, які найбільше відчувають міграційні процеси.

\section{Список використаних джерел:}

1. Берегова Г.І., Козицький В.А. Проблеми міграції: модель системної динаміки. Науковий вісник Херсонського державного університету. Серія «Економічні науки». 2018. № 2(29). С. 195-199.

2. Войтович Р. Глобальна міграція та ії виклики суспільному розвитку. Збірник наукових праць Національної академії державного управління при Президентові України. 2010. № 2. С. 3-15.

3. Дмитрук Б.П., Свєтлова Н.М. Світові міграційні процеси: мотивація, види й наслідки для країн виїзду та приймаючих країн. Вісник Східноєвропейського університету економіки і менеджменту. Серія «Економіка і менеджмент». 2016. № 1. C. 18-27.

4. Batsaikhan U., Darvas Z., Raposo I. People on the move: migration and mobility in the European Union. Bruegel Blueprint Series 28. 2018.

5. Kurekova L., Hejdukova P. Interregional migration and globalization: the empirical study in selected countries. Proceedings of 17 th International Scientific Conference Globalization and Its Socio-Economic Consequences. Rajecke Teplice. Slovakia. 2017. P. 1243-1250.

6. Lukianenko I., Novik A. The Dynamic Modelling of Migration Flows in Ukraine in the Context of Globalization. Proceedings of 18th International Scientific Conference: Globalization and Its Socio-Economic Consequences (10th-11th October 2018). Parti. - Economic Impact of Migration. P. 276-281.

7. McAuliffe M., Khadria B. World Migration Report 2020. URL : https://publications.iom.int/system/files/pdf/wmr_2020. pdf (дата звернення: 17.12.2019).

8. Oliskevych M., Lukianenko I. Structural Change and Labor Market Integration: Evidence from Ukraine. International Journal of Economics and Financial Issues. 2017. № 7(3). P. 501-509.

9. Oliskevych M., Barabash G., Dosyn K. System dynamics approach to modeling of migration in Ukraine. Проблеми системного підходу в економіці. 2018. № 1. С. 185-190.

10. Puraite A., Saulius G., Birute P., Danguole S. Tendencies of International Migration in Europe: is it Possible to Control Migration and its Impact on Public Security in Europe in an Era of Globalization? Proceedings of 17th International Scientific Conference Globalization and Its Socio-Economic Consequences. Rajecke Teplice. Slovakia, 2017. P. 2120-2126.

11. Integrated Modelling of European Migration / J. Raymer et al. Journal of the American Statistical Association. 2013. № 108(503). P. 801-819. URL : http://www.tandfonline.com/doi/abs/ 10.1080/01621459.2013.789435 (дата звернення: 15.12.2019).

\section{References:}

1. Berehova H. I., Kozytskyi V. A. (2018). Problemy mihratsii: model systemnoi dynamiky [Migration problems: a model of system dynamics]. Scientific Bulletin of Kherson State University. Economic Sciences Series, vol. 2, no 29, pp.195-199.

2. Voitovych R. (2010). Hlobalna mihratsiia ta yii vyklyky suspilnomu rozvytku [Global migration and its challenges to social development]. Proceedings of the National Academy of Public Administration under the President of Ukraine, no. 2, pp. $3-15$. 
3. Dmytruk B. P., Svietlova N. M. (2016). Svitovi mihratsiini protsesy: motyvatsiia, vydy y naslidky dlia krain vyizdu ta pryimaiuchykh krain [World migration processes: motivation, types and consequences for countries of departure and destination]. Bulletin of the Eastern European University of Economics and Management. Series: Economics and Management, vol.1, pp. 18-27.

4. Batsaikhan U., Darvas Z., Raposo I. G. (2018). People on the move: migration and mobility in the European Union. Bruegel Blueprint Series 28, 22 January 2018.

5. Kurekova L., Hejdukova P. (2017). Interregional migration and globalization: the empirical study in selected countries. Proceedings of 17 th International Scientific Conference Globalization and Its Socio-Economic Consequences. Rajecke Teplice, Slovakia, pp. 1243-1250.

6. Lukianenko I., Novik A. The Dynamic Modelling of Migration Flows in Ukraine in the Context of Globalization. Proceedings of 18th International Scientific Conference: Globalization and Its Socio-Economic Consequences (10th-11th October 2018). Parti. Economic Impact of Migration. Pp. 276-281.

7. McAuliffe M., Khadria B. World Migration Report 2020. URL: https://publications.iom.int/system/files/pdf/wmr 2020.pdf

8. Oliskevych M., Lukianenko I. (2017). Structural Change and Labor Market Integration: Evidence from Ukraine. International Journal of Economics and Financial Issues, vol. 7(3), pp. 501-509.

9. Oliskevych M., Barabash G., Dosyn K. (2018). System dynamics approach to modeling of migration in Ukraine. Problems of systematic approach in economy, vol. 1, pp. 185- 190.

10. Puraite A., Saulius G., Birute P. and Danguole S. (2017). Tendencies of International Migration in Europe: is it Possible to Control Migration and its Impact on Public Security in Europe in an Era of Globalization? Proceedings of 17th International Scientific Conference Globalization and Its Socio-Economic Consequences, Rajecke Teplice, Slovakia, pp. 2120 - 2126.

11. Raymer J. et al. Integrated Modelling of European Migration (2013). Journal of the American Statistical Association, vol. 108 (503), pp. 801-819. URL: http://www.tandfonline.com/doi/abs/10.1080/01621459.2013.789435.

\author{
Nehrey Maryna \\ National University of Life and Environmental Sciences of Ukraine \\ Komar Mariana \\ Ivan Franko National University of Lviv
}

\title{
MODELING MIGRATION PROCESSES UNDER THE UNCERTAINTY OF ECONOMIC POLICY
}

The article is devoted to the study of the problem of modern migration processes and the assessment of the impact of economic policy uncertainty on migration in EU countries. The structure of migration was evaluated and the main trends of migration processes were determined. Long-term research has shown that international migration is uneven across the globe, but is shaped by economic, geographical, demographic and other factors, leading to different migration patterns, such as migration "corridors" that have formed over the years. In recent years, there has been a deepening of existing migration models, as opportunities have been realized through economic growth and reform, trade liberalization and long-term stability. The influence of migration on social processes is determined. The connection between economic, political and social issues on the one hand and migration on the other is illustrated. The importance of digitalization in migration processes is shown. The scale and pace of international migration is difficult for forecasting, as migration processes are closely linked to unpredictable events (such as economic crisis or military conflict) and long-term trends (demographic changes, economic development, digitalization and access to transport). The unprecedented pace of change in the geopolitical, social, environmental and technological spheres has led to the pace of change exceeding all expectations and projections. Such changes often lead to unexpected and undesirable consequences. Within these shifts, international migration is increasingly being used as a political tool, undermining democracy and creating understandable fears in the public, resulting from the accelerating pace of change and the growing uncertainty of our time. The influence of economic policy uncertainty on migration processes is investigated. To explore the impact of policy uncertainty on aggregate investment, production, and employment, they use a new approach - the Economic Policy Uncertainty (EPU). Regression models have been constructed to conclude that there is no direct correlation between economic policy uncertainty and migration over the relevant time period.

Key words: migration, migration process, uncertainty, economic policy uncertainty index, regression model.

JEL classification: C01, C25, J60, E66, F02. 